\title{
Artificial Weathering of Heat-treated Pines from the Iberian Peninsula
}

\author{
Bruno M. Esteves, ${ }^{\mathrm{a}, *}$ René Herrera,${ }^{\mathrm{b}}$ Jorge Santos, ${ }^{\mathrm{c}}$ Luísa Carvalho, ${ }^{\mathrm{c}}$ Lina Nunes, ${ }^{\mathrm{d}}$ \\ José Ferreira, ${ }^{\mathrm{a}}$ Idalina J. Domingos, ${ }^{\mathrm{a}}$ and Luísa Cruz-Lopes ${ }^{\mathrm{a}}$
}

\begin{abstract}
Samples from the two most common pines grown in Portugal (Pinus pinaster Ait) and Spain (Pinus radiata, D. Don) were heat-treated in industrial facilities in accordance with ThermoWood $\AA$ class D. For both species, the variation in surface properties, of untreated and heat-treated wood after artificial weathering from 75 to $750 \mathrm{~h}$, is presented. The analysis included the determination of color, roughness, gloss, and wettability before exposure and after each artificial weathering period. Untreated woods became darker faster, while in heat-treated woods, lightness remained approximately constant until $750 \mathrm{~h}$ of artificial weathering. Both untreated and heat-treated wood became more reddish in the beginning of the weathering process, turning greener for longer exposure times. Untreated woods became yellower in the beginning, turning into blueish tones later. Heat-treated wood turned slightly yellower until $750 \mathrm{~h}$ of weathering. Gloss decreased for untreated wood with no significant changes in heat-treated wood. Despite the changes, the gloss of both untreated and heat-treated wood converged to similar values. Roughness increased for both untreated and heat-treated woods. Artificial weathering increased the wettability of heat-treated wood.
\end{abstract}

Keywords: Artificial weathering; Heat treatment; Pinus pinaster; Pinus radiata

Contact information: a: Department of Wood Engineering and CERNAS-IPV Research Centre, Polytechnic Institute of Viseu, Portugal; $b$ : Chemical and Environmental Engineering Department, University of the Basque Country, 20018, Donostia-San sebastián, Spain and InnoRenew CoE, Livade 6, 6310, Izola, Slovenia; c: DEMad, Instituto Politécnico de Viseu, 3504-510 Viseu, Portugal and LEPABE - Faculty of Engineering, University of Porto, 4200-465, Porto, Portugal; d: National Laboratory for Civil Engineering (LNEC), Lisboa, Portugal and Centre for Ecology, Evolution and Environmental Changes (CE3C), Azorean Biodiversity Group, University of the Azores, Angra do Heroísmo, Portugal;

* Corresponding author: bruno@estgv.ipv.pt

\section{INTRODUCTION}

Heat treatment is a well-known modification procedure that increases wood stability and durability (Esteves and Pereira 2009). One of the most successful commercial processes is the Thermowood ${ }^{\circledR}$ process, which started in Finland but is now applied in several countries including Sweden, Turkey, Japan, Spain, and Portugal. The treatment is done with steam, with less than 3 to $5 \%$ oxygen, without pressure, and with a minimum air speed of $10 \mathrm{~m} / \mathrm{s}$. The process begins with a rapid increase in temperature of the oven with heat and steam up to $100{ }^{\circ} \mathrm{C}$, followed by a gradual increase up to $130{ }^{\circ} \mathrm{C}$ to near zero humidity. Then, heat treatment is made at a chosen temperature between $185^{\circ} \mathrm{C}$ to $230{ }^{\circ} \mathrm{C}$ for 2 to $3 \mathrm{~h}$. Finally, the temperature decreases to 80 to $90{ }^{\circ} \mathrm{C}$ (Mayes and Oksanen 2002).

Deterioration by abiotic agents such as solar radiation, rain, snow and sleet, wind and humidity changes are generally linked to weather exposure conditions (Feist et al. 2007). These atmospheric agents can cause color changes as well as chemical, physical, 
mechanical, and anatomical changes on the surface of the wood. These changes occur on the surface to a depth of 0.05 to $2.5 \mathrm{~mm}$ during the initial period.

Solar radiation affects wood due mainly to the UV component, which causes photochemical damage in lignin and extractives. UV degradation is driven by free radicals formed by the oxidation of phenolic hydroxides (Buchner et al. 2019; Derbyshire and Miller 1981; Feist et al. 2007)

Mechanical damage on the surface is a result of retraction and swelling of the wood, which may also lead to cracks. For instance, Xing et al. (2015) stated that small cracks in untreated and heat-treated wood could be observed by SEM analysis. In accordance to Yildiz et al. (2013), effects relative to mechanical properties depend on the species, and generally hardwood species behave better than softwood with respect to weathering.

With the leaching of soluble compounds, the most photo-resistant compounds are exposed in the surface, leading to their degradation. With time, the wood acquires a greyish tone due to the residual cellulose and blue stain fungal growth (Feist et al. 2007; Oberhofnerová and Pánek 2016).

There have been several attempts to predict service life of wood above ground, such as the work of Meyer-Veltrup et al. (2017), taking into account wood species, their durability classes, wetting abilities, temperature, and moisture content, as also mentioned by Oberhofnerová and Pánek (2016). One difficulty in estimating wood service life in Europe is the variability of climates between regions, particularly the average number of sunshine hours per year. Cities such as Lisbon, Madrid, or Athens show an average well above $2500 \mathrm{~h}$ of sunshine per year, far superior to the values measured on Northern European countries, which are typically bellow $1800 \mathrm{~h}$ per year. The expected level of degradation by UV radiation is thus significantly higher in Southern Europe, though most wood modification developments were initially targeted to Nordic countries. On the other hand, the precipitation levels are higher in Northern, compared to Southern Europe, and the differences are increasing (Van den Besselaar et al. 2013).

Thermally treated wood has a very different chemical composition than the original wood. The percentage of hemicelluloses is much lower, but lignin levels increase significantly (Alén et al. 2002; Windeisen et al. 2007; Esteves et al. 2008). Because UV radiation mainly attacks lignin, heat-treated wood might be more affected by UV radiation. However, the color variations of treated wood subject to UV are smaller than the variation in untreated samples (Ayadi et al. 2003; Deka et al. 2008; Miklecic et al. 2011), which according to Ayadi et al. (2003) is due to the stabilization of lignin during heat treatment. Nuopponen et al. (2005) reported that treated wood is more resistant when exposed to weather conditions because the degradation products of lignin are less leached than those of untreated wood. This might be due to the fact that during heat treatment, low molecular weight water extractable components react to produce insoluble high molecular weight compounds. The color variation depends heavily on the initial color of the wood. Typically, darker woods (such as heat-treated wood) become lighter, while lighter woods become darker initially and then lighter when they acquire a gray/silver tone. This phenomenon has been described by several authors (Temiz et al. 2006; Olărescu et al. 2014; Kucuktuvek et al. 2017). Xing et al. (2015) stated that the color changes of the wood surface are due to the removal of extractives and the modification of lignin.

One of the great advantages of thermally treated wood with regard to resistance to atmospheric agents is that they suffer less swelling and shrinkage with variations in wood moisture content. In accordance to Humar et al. (2020), thermally modified wood during the course of weathering has lower moisture content in comparison to untreated Norway 
spruce.

This work was done in the framework of the project PROJ/CI\&DETS/2016/0010Determination of resistance of thermally treated wood to weather conditions in different countries (HTW). The goal of this project was to study the degradation of thermally modified wood by Thermowood ${ }^{\circledR}$ process in countries where solar radiation is higher, i.e., Portugal and Spain, and compare it to accelerated weathering. The objective of this part of the work was to determine the changes on the surface of the most used heat-treated pines from the Iberian Peninsula after artificial weathering.

\section{EXPERIMENTAL}

\section{Materials}

Pine samples from the two most common pines grown in Portugal (Pinus pinaster Ait) and in Spain (Pinus radiata D. Don) were treated in industrial facilities at $212{ }^{\circ} \mathrm{C}$ in accordance to the Thermowood $\AA$ process using Thermo D class specifications. Boards were cut into samples of approximately $150 \mathrm{~mm}$ x $50 \mathrm{~mm}$ x $10 \mathrm{~mm}$.

\section{Methods}

\section{Artificial weathering}

Seven specimens $(150 \mathrm{~mm} \times 50 \mathrm{~mm} \times 10 \mathrm{~mm})$ for each treated/untreated wood were positioned in a QUV accelerated weathering tester (Q-LAB, Homestead, FL, USA) from $75 \mathrm{~h}$ to $750 \mathrm{~h}$. The measurements were made at $0 \mathrm{~h}, 75 \mathrm{~h}, 150 \mathrm{~h}, 300 \mathrm{~h}, 450 \mathrm{~h}, 600 \mathrm{~h}$, and $750 \mathrm{~h}$ of artificial weathering. This chamber replicates the damage caused by sunlight and dew. The exposure to UVA lamps followed the conditions of the cycle $n^{\circ} 1$ (method A) of EN ISO 16474-3 (2013). The specimens were cycled through periods of UV radiation exposure followed by periods of no radiation, during which temperature changes occur. The cycle consisted of $4 \mathrm{~h}$ of dry UV exposure at a black-standard temperature of $(60 \pm 3)$ ${ }^{\circ} \mathrm{C}$ followed by $4 \mathrm{~h}$ of condensation exposure, without radiation, at a black-standard temperature of $(50 \pm 3){ }^{\circ} \mathrm{C}$.

\section{Color determination}

The color was analyzed in a portable spectrophotometer COLOREYE ${ }^{\circledR}$ XTH (Gretag Macbeth, Grand Rapids, MI USA), before and after being exposed to accelerated weathering. Color parameters were determined using an average of three measurements made in the weathered surface (Fig. 1) by the CIELAB system. This system is composed of three parameters: $L^{*}$ that represents lightness and varies from 100 (white) to zero (black), and two color tones ( $a^{*}$ and $\left.b^{*}\right)$, where $a^{*}$ goes from red $(+a)$ to green $(-a)$, while $b^{*}$ goes from yellow $(+b)$ to blue $(-b)$.

\section{Gloss determination}

Gloss was determined parallel to the wood fibers with a gloss meter REFO-3D (DR Lange, Düsseldorf, Germany) with three-angle geometry $20^{\circ}, 60^{\circ}$, and $85^{\circ}$. Gloss was determined for untreated and heat-treated maritime pine and radiata pine woods before and after artificial weathering using an average of three measurements made in the surface. 


\section{Roughness determination}

Roughness was measured in a Surftest SJ-400 (Mitutoyo, Illinois, United States). Average roughness $\left(R_{\mathrm{a}}\right)$ and the maximum height of the roughness profile $\left(R_{\mathrm{z}}\right)$, calculated as the average distance between the highest peak and lowest valley in each sampling length, were determined for both untreated and heat-treated woods before and after artificial weathering.

\section{Wettability}

The wettability was determined by measuring the contact angles using the sessile drop method in a Contact Angle System OCA20 (DataPhysics Instruments, Filderstadt, Germany), a video-based measuring device equipped with software for image analysis. The measurements were performed parallel to wood fibers, and distilled water was used as probe liquid. The droplet volume was $4 \mu \mathrm{L}$. Contact angles were measured during approximately $50 \mathrm{~s}$, allowing the droplets to reach equilibrium. The initial value was used.

\section{Statistical analysis}

Statistical analysis was performed using IBM® SPSS® V26 edition. Two-way ANOVA was made to test if there was a difference between heat treatment and weathering for color $\left(L^{*}, a^{*}\right.$, and $\left.b^{*}\right)$, gloss $\left(20^{\circ}, 60^{\circ}\right.$, and $\left.85^{\circ}\right)$ and roughness $\left(R_{\mathrm{a}}\right.$ and $\left.R_{\mathrm{z}}\right)$ for Pinus pinaster and Pinus radiata woods. One-way ANOVA was done for each untreated and heat-treated wood during weathering. Average and standard deviations were determined whenever possible.

\section{RESULTS AND DISCUSSION}

Figure 1 presents the surface changes of untreated and heat-treated maritime and radiata pine in the course of the artificial weathering process. As expected, untreated woods become darker, even with only $75 \mathrm{~h}$ of weathering (second sample), during the weathering process. The differences, for heat-treated samples, were more difficult to track visually. There was a slight color change along the treatment, which was clearly more pronounced for heat-treated maritime pine, probably due to its initial darker color.

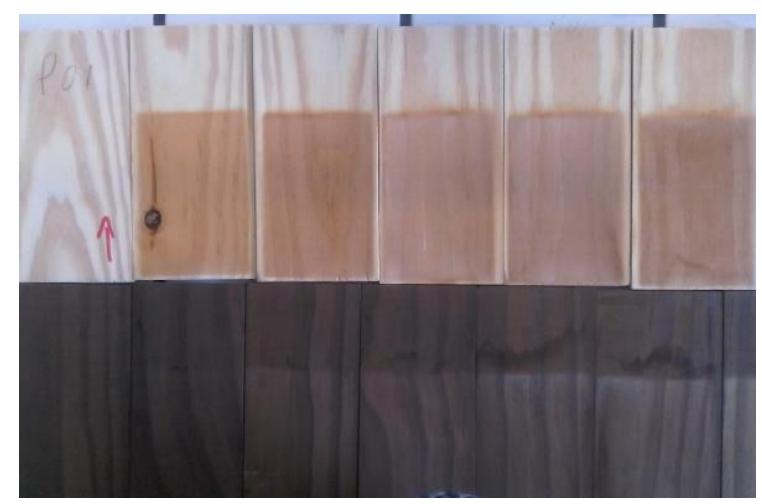

(a)

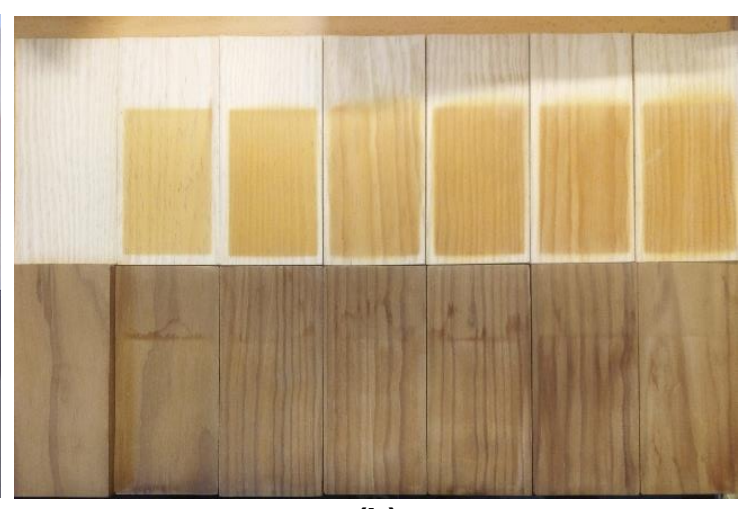

(b)

Fig. 1. Changes due to artificial weathering in the surface of (a) P. pinaster (b) P. radiata. Untreated (first row) and heat-treated (second row). 
Almost no differences were seen with respect to the color of heat-treated radiata pine. As expected, the color variation during the weathering process depends on the initial color of the wood. The darkest wood - maritime pine heat-treated wood-became lighter, whereas the lighter untreated pine woods became darker. Similar results were presented previously (Temiz et al. 2006; Olărescu et al. 2014; Kucuktuvek et al. 2017).

Figure 2 presents the average lightness in the course of the weathering process for untreated and heat-treated maritime and radiata pine. Standard deviation is shown as error bars in the figure. For untreated maritime pine, lightness $\left(L^{*}\right)$ decreased in the first $150 \mathrm{~h}$ of weathering from 76 to about 65, staying approximately constant until about $600 \mathrm{~h}$, decreasing afterwards to about 54 . The behavior of untreated radiata pine $L^{*}$ was similar, although there was a higher decrease between 450 and $600 \mathrm{~h}$ of weathering, reaching a minimum of 50 . With $750 \mathrm{~h}$, the $L^{*}$ value was very similar to that of maritime pine, 52 . Standard deviation for untreated and heat-treated woods $L^{*}$ is very small showing low dispersion of values. ANOVA results presented in Table 2 show that $L^{*}$ is significantly different during weathering for untreated woods.

口Untreated pinaster $\mathbf{\$}$ Treated pinaster $\mathbf{\square}$ Untreated radiata $₫$ Treated radiata

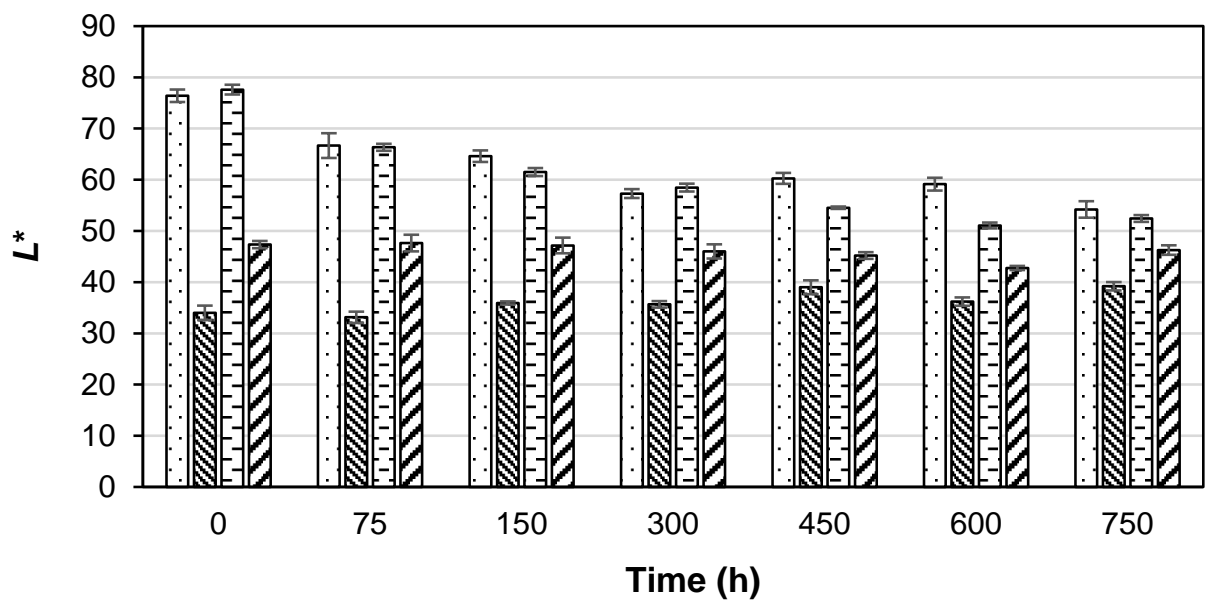

Fig. 2. $L^{*}$ variation in the course of the weathering process for untreated and heat-treated maritime and radiata pines

Heat-treated radiata pine $L^{*}$ was almost the same during the weathering process, ranging from 48 to 43 . Nevertheless, there is a statistically significant difference during weathering, which only shows that is at least one average that differs significantly from the remaining (Table 2. In relation to heat-treated maritime pine, there was an increase in lightness in the course of the weathering process from the initial 34 to the final 39 . This difference can be seen in Fig. 1. Initial heat-treated radiata pine was lighter than heattreated maritime pine with lightness 47 and 34, respectively. However, the difference between the lightness of both woods decreased as a consequence of the weathering process. There was a similar trend between untreated and heat-treated pines, where the differences in lightness decreased with weathering. The results show that heat-treated wood lightness is more stable with the weathering process than that of untreated wood, as described before (Ayadi et al. 2003). Nevertheless, this higher stability might be due also to the initial lightness of heat-treated wood, which is much darker than untreated woods. The increase in lightness for heat-treated wood was described for jack pine (Kocaefe et al. 2013), 
Oriental beech (Turkoglu et al. 2015), Scots pine, spruce, iroko, and ash (Yildiz et al. 2013). However, Gonzalez de Cademartori et al. (2015) exposed three fast growing eucalyptus to natural weathering for 360 days and concluded that lightness decreased.

Artificial weathering mostly affects lignin. Even though heat-treated wood has more lignin than untreated wood, the higher resistance of heat-treated wood may be due to lignin stabilization during heat treatments (Ayadi et al. 2003). Polyphenols (lignin and tannins) react at high temperature, by self-condensation or by copolymerization with other compounds that are produced in the heat treatment. It is expected that, if the weathering is prolonged, lightness will be very similar regardless of the initial values (Huang et al. 2012a), and that was verified in the present study.

The parameter $a^{*}$ increased for both untreated pines in the beginning of the weathering process until about $300 \mathrm{~h}$ for maritime pine and $400 \mathrm{~h}$ for radiata pine, decreasing later on until $750 \mathrm{~h}$. The values for $a^{*}$ after $750 \mathrm{~h}$ were higher than the initial ones, indicating some reddening of the samples. In relation to heat-treated woods, $a^{*}$ increased until $450 \mathrm{~h}$ of weathering, staying approximately constant afterwards (Fig. 3).

$\square$ Untreated pinaster $\mathbf{\$}$ Treated pinaster $\square$ Untreated radiata $\square$ Treated radiata

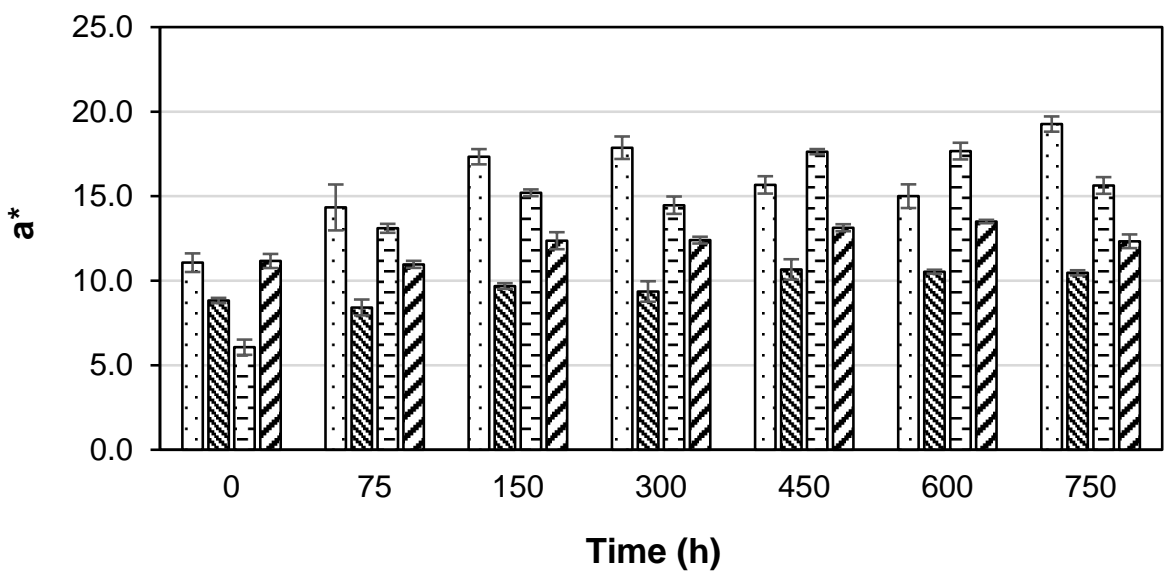

$\square$ Untreated pinaster $\$$ Treated pinaster $\boxminus$ Untreated radiata $\square$ Treated radiata

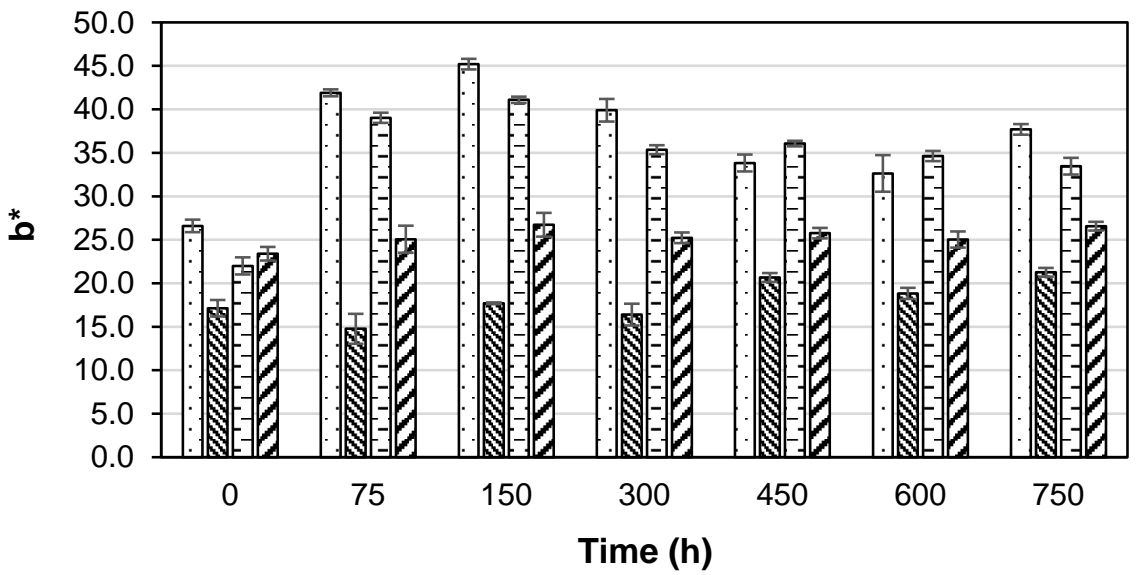

(a)

(b)

Fig. 3. Parameters $a^{*}$ and $b^{*}$ variation in the course of the weathering process for untreated and heat-treated maritime and radiata pine 
The $b^{*}$ parameter followed a similar pattern, with an increase followed by a decrease with weathering for untreated woods and a slight increase with weathering for both heat-treated woods. All final $b^{*}$ values were higher than initial ones, showing a yellowing of the surface (Fig. 3). All $a^{*}$ and $b^{*}$, for untreated and heat-treated wood, were considered to be statistically different with weathering, as can be seen in Table 2. Similar results were presented for heat-treated Scots pine aged for $500 \mathrm{~h}$ with an increase in both $a^{*}$ and $b^{*}$ (Kucuktuvek et al. 2017).

Different results were reported for heat-treated Oriental beech (Turkoglu et al. 2015), jack pine (Kocaefe et al. 2013), and for three different eucalyptus woods exposed to natural weathering, which all showed a decrease in both $a^{*}$ and $b^{*}$ (Gonzalez de Cademartori et al. 2015). According to Yildiz et al (2013) artificial weathering for $400 \mathrm{~h}$, $600 \mathrm{~h}$, and $1200 \mathrm{~h}$ produced greenish and bluish surfaces on heat-treated Scots pine, spruce, iroko, and ash wood. The effect was higher for heat-treated pine and iroko samples. These different results might be due to the initial color of untreated woods but also to the number of hours of weathering.

Figure 4 presents the glossiness variation along the weathering process for untreated and heat-treated wood measured at $20^{\circ}, 60^{\circ}$, and $85^{\circ}$ angles. At $20^{\circ}$ and $60^{\circ}$, the gloss of heat-treated wood was lower than untreated woods, as reported before (Ayata $e t$ al. 2017a,b; Esteves et al. 2019). For untreated wood, glossiness decreased with the weathering process until about $400 \mathrm{~h}$ of weathering, staying approximately constant afterwards.

Although radiata pine had a higher initial gloss than maritime pine, both pines had similar gloss after $400 \mathrm{~h}$ of weathering. This decrease was seen on the $20^{\circ}$ and $60^{\circ}$ angles. The statistical significative difference was confirmed by one-way ANOVA in Table 2. The correct angle for glossiness determination should be $85^{\circ}$ due to the matte surface presented by the untreated and heat-treated samples with glossiness lower than $30 \mathrm{GU}$. However, the values for $85^{\circ}$ have a very high dispersion, as can be seen by the high standard deviations on Fig. 4c. This can be due to surface irregularities that usually decrease the measured value of gloss, especially at higher angles (Bekhta et al. 2014).

Regarding heat-treated wood at $20^{\circ}$, there were few changes along the weathering process, which is in accordance with ANOVA tests that show no significant differences in the course of weathering (Table 2). At $60^{\circ}$, there was a small decrease of gloss for heattreated radiata pine and a little increase for heat-treated maritime pine, which was enough, however, to consider the differences during weathering significantly different (Table 2). Despite of all the changes, the gloss of both untreated and heat-treated wood converged to similar values in the course of the weathering process, mainly at $20^{\circ}$ and $60^{\circ}$.

There are conflicting reports on the gloss changes due to artificial or natural weathering. Kucuktuvek et al. (2017) noted that heat treatments at $210{ }^{\circ} \mathrm{C}$ and $220{ }^{\circ} \mathrm{C}$ increase the surface gloss of Scots pine after weathering. Turkoglu et al. (2015) exposed Oriental beech to natural weathering for three months, demonstrating that gloss decreases for aged heat-treated wood and that this decrease is higher than in untreated wood. Similar results were presented for heat-treated Scots pine after accelerated weathering (Baysal et al. 2014); the changes in gloss were lower for heat-treated wood, similar to the results presented here. 
$\square$ Untreated pinaster $\leqslant$ Treated pinaster $\square$ Untreated radiata $\square$ Treated radiata

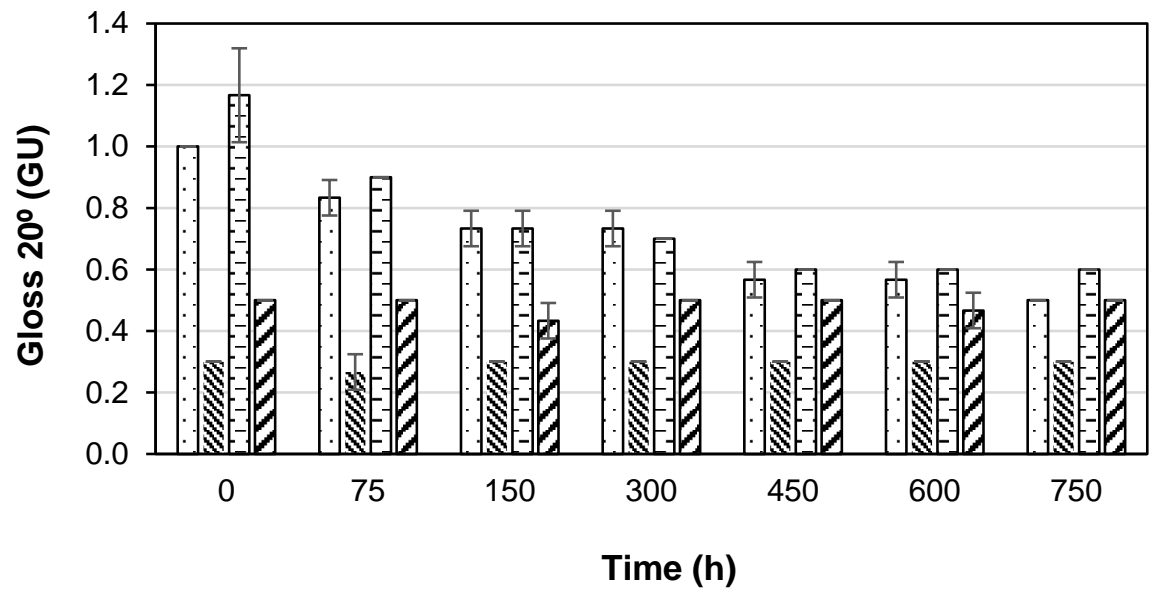

(a)

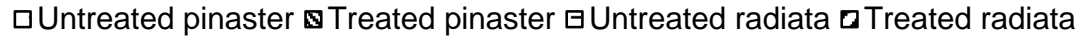

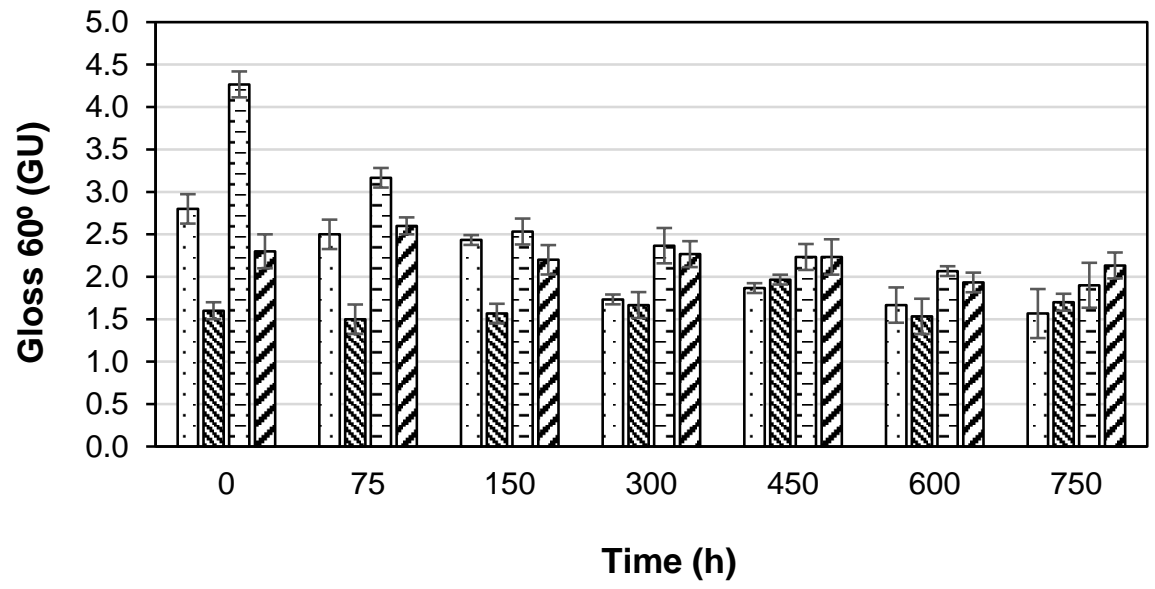

(b)

$\square$ Untreated pinaster $\mathbf{s}$ Treated pinaster $\boxminus$ Untreated radiata $\mathbf{0}$ Treated radiata

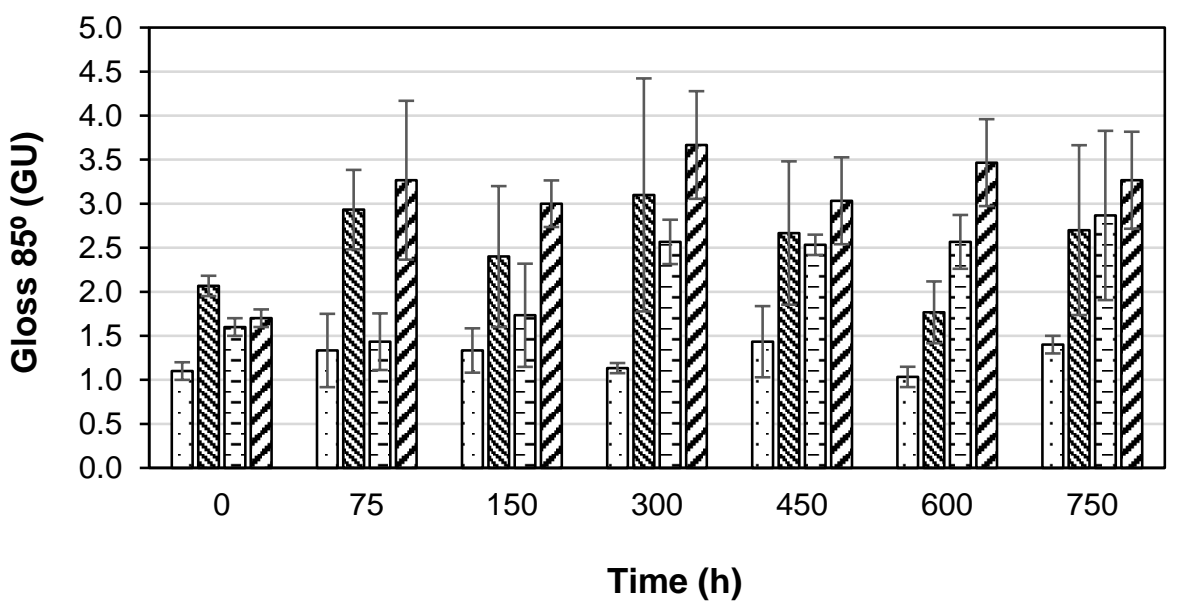

(c)

Fig. 4. Gloss at $20^{\circ}(\mathrm{a}), 60^{\circ}$ (b) and $85^{\circ}$ (c) variation in the course of the weathering process for untreated and heat-treated maritime and radiata pine 
The roughness variation during the weathering process is shown in Fig. 5. For untreated wood, $R_{\mathrm{a}}$ increased in the beginning until about $300 \mathrm{~h}$ of exposure, decreasing slightly after that though with some small variations. Overall, roughness $\left(R_{\mathrm{a}}\right)$ increased for untreated wood. For heat-treated wood, there was a general increase in roughness for both heat-treated maritime and radiata pines. All the differences of $R_{\mathrm{a}}$ in the course of weathering were considered to be statistically different during weathering (Table 2).

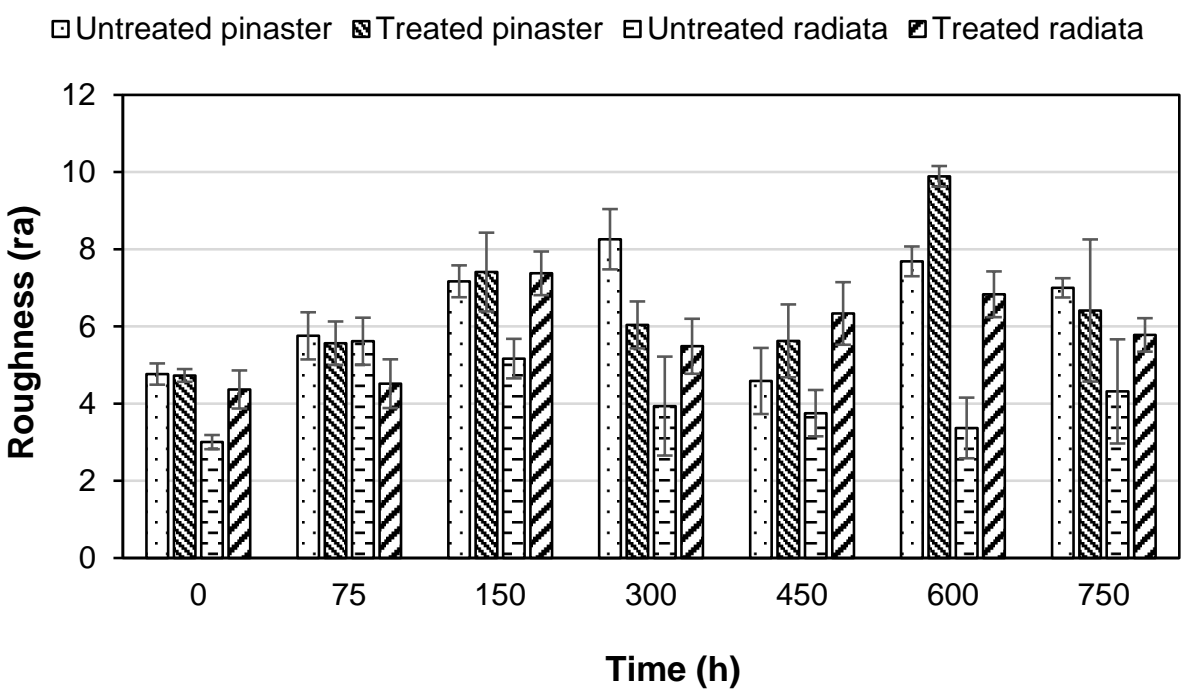

(a)

$\square$ Untreated pinaster $\mathbf{\mathrm { N }}$ Treated pinaster $\boxminus$ Untreated radiata $\nabla$ Treated radiata

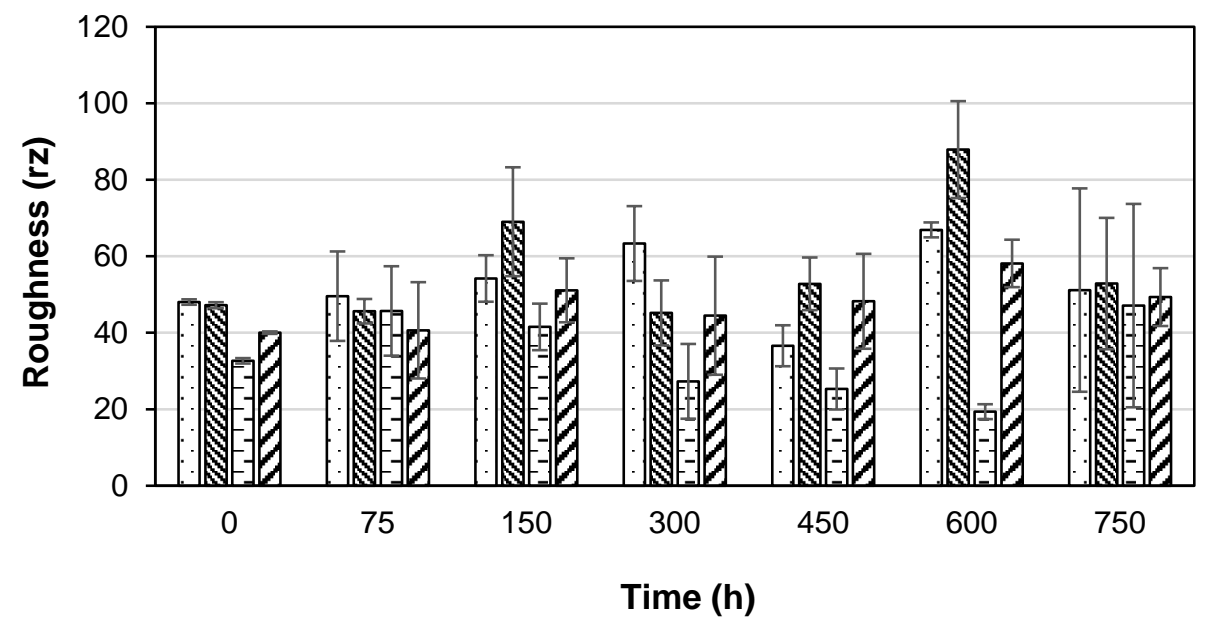

(b)

Fig. 5. Changes due to artificial weathering in the surface roughness of untreated and heattreated maritime and radiata pine. $R_{\mathrm{a}}$ values (a) and $R_{\mathrm{z}}$ values (b).

Since $R_{\mathrm{z}}$ values represent the maximum peak to valley height of the profile, their values can be influence by several irregularities in the samples. Nonetheless $R_{\mathrm{z}}$ exhibited a trend similar to $R_{\mathrm{a}}$ values with the exception of treated radiata pine, where the difference during weathering was not statistically significant (Table 2). The higher standard deviations of $R_{\mathrm{z}}$ values (Fig. 5b) in relation to $R_{\mathrm{a}}$ values (Fig. 5a) show that $R_{\mathrm{Z}}$ values have a higher dispersion of values than $R_{\text {a }}$. Similarly, Turkoglu et al. (2015) stated that 
roughness increased for both untreated and heat-treated Oriental beech. Kucuktuvek et al. (2017) tested untreated and heat-treated Scots pine at temperatures between 210 to $230{ }^{\circ} \mathrm{C}$ before and after natural weathering for 6 months, concluding that roughness increases with weathering for both untreated and heat-treated wood nevertheless the increase was higher for untreated wood. Baysal et al. (2014) reported an increase in $R_{\mathrm{z}}$ but a decrease in $R_{\mathrm{a}}$ parameter for Scots pine roughness after artificial weathering. Yildiz et al. (2013) determined the $R_{\mathrm{z}}$ roughness value for heat-treated Scots pine, spruce, iroko, and ash and concluded that roughness depended on the species. While $R_{\mathrm{z}}$ values tended to decrease after weathering for Scots pine, in spruce there was a decrease followed by an increase. For iroko and ash, there was a clear increase along the weathering process.

Figure 6 presents the changes due to artificial weathering in the contact angle (wettability) of untreated and heat-treated woods. In untreated woods, there were some oscillations in the contact angle with weathering, but there were no observable changes in relation to initial values. Therefore, weathering did not greatly change the wettability of the untreated wood surface. In treated woods, there was a clear decrease in the contact angle measured in the surface, which corresponded to an increase in wettability. This increase was observed for both heat-treated pines. For $750 \mathrm{~h}$ the contact angle decreased for under $20^{\circ}$ for radiata pine and for about $50^{\circ}$ for maritime pine wood. The initial contact angle was higher for heat-treated maritime pine wood. Parallel results were reported in three different eucalypt species where wettability increased for all heat-treated samples (Gonzalez de Cademartori et al. 2015) or with jack pine heat-treated at $210{ }^{\circ} \mathrm{C}$ (Kocaefe et al. 2013). The reasons for this increase in wettability were mentioned by Gindl et al. (2006) to be due to the cleaning of wood surface done by UV irradiation that increased both the wettability and surface free energy. However, Huang et al. (2012b) noted that this increase is possible due to the formation of cracks during weathering, which they confirmed by scanning electron microscopic analysis.

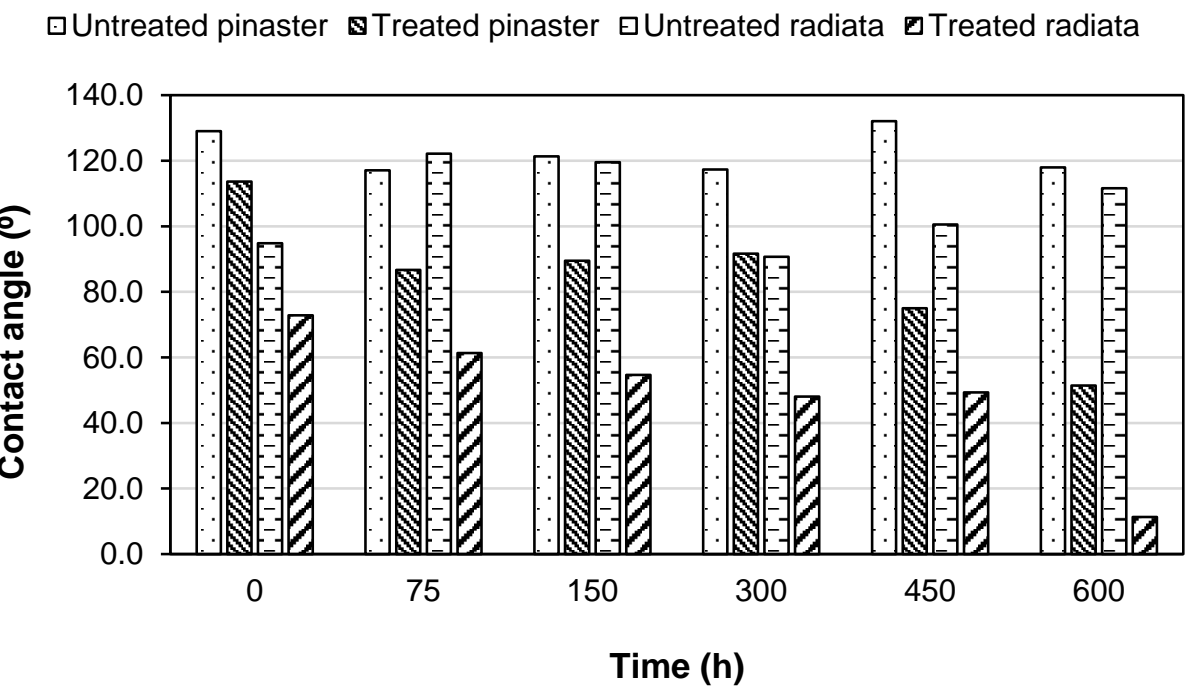

Fig. 6. Changes due to artificial weathering in the contact angle (wettability) of untreated and heat-treated maritime and radiata pine

Table 1 presents the results for an analysis of variance (ANOVA) of color, gloss and roughness parameters with heat treatment and weathering fixed factors (only interaction significance level is presented). Results show that interaction between both 
factors is significant for all the variables with the exception of $85^{\circ}$ Gloss for Pinus pinaster. The non-significance of $85^{\circ}$ gloss is most probably due to the high dispersion of results for this angle, as can be seen by the high standard deviation on Fig. 4 . Therefore, and because there was a high significance level for the cross-effects (heat treatment $x$ weathering level), single effects must be evaluated. These effects are presented in Table 2.

Table 1. Two-way ANOVA for Color, Gloss, and Roughness Parameters with Heat Treatment and Weathering Fixed Factors for Pinaster and Radiata Woods Interaction Significance Level ( $p$-value)

\begin{tabular}{|l|c|c|c|c|c|c|c|c|}
\hline \multicolumn{1}{|c|}{ Test } & $L^{*}$ & $a^{*}$ & $b^{*}$ & $\begin{array}{c}\text { Roughness } \\
\left(R_{\mathrm{a}}\right)\end{array}$ & $\begin{array}{c}\text { Roughness } \\
\left(R_{\mathrm{z}}\right)\end{array}$ & $\begin{array}{c}\text { Gloss } \\
20^{\circ}\end{array}$ & $\begin{array}{c}\text { Gloss } \\
60^{\circ}\end{array}$ & $\begin{array}{c}\text { Gloss } \\
85^{\circ}\end{array}$ \\
\hline Source & \multicolumn{8}{|c|}{ Treat * Weathering time } \\
\hline P. pinaster & 0.000 & 0.000 & 0.000 & 0.002 & 0.008 & 0.000 & 0.000 & 0.616 \\
\hline P. radiata & 0.000 & 0.000 & 0.000 & 0.001 & 0.042 & 0.000 & 0.000 & 0.050 \\
\hline
\end{tabular}

Table 2 presents the results for a one-way analysis of variance (ANOVA) to study the effects of weathering on color, gloss and roughness parameters. The color parameters were considered statistically significantly different for all untreated and heat-treated woods during weathering. Nevertheless, although statistically significant, the differences for heat treated woods for $L^{*}$ were very small, as can be seen in Fig. 2 . Gloss at $20^{\circ}$ was statistically different for the untreated samples, but not for the heat-treated ones. This reinforces what was said before. Untreated wood gloss at $20^{\circ}$ remained approximately constant in the course of the weathering process. Although gloss at $60^{\circ}$ was significantly different during weathering, the significance values show that this was probably due to one or two means that are different from the others (Fig. 4b). In relation to the $85^{\circ}$, results are most likely influenced by the high dispersion of values as seen in Fig. 4c. Roughness was significantly different for untreated and heat-treated samples during weathering, except for $R_{\mathrm{z}}$ values of untreated and treated Pinus radiata woods.

Table 2. One-way ANOVA for Color, Gloss, and Roughness Parameters with Weathering for Pinus pinaster and radiata Woods

\begin{tabular}{|l|l|l|l|l|}
\hline Weathering & \multicolumn{4}{|l|}{ Significance level (p-value) } \\
\hline Test & $\begin{array}{l}\text { Untreated } \\
\text { P. pinaster }\end{array}$ & $\begin{array}{l}\text { Untreated } P . \\
\text { radiata }\end{array}$ & $\begin{array}{l}\text { Treated } P . \\
\text { pinaster }\end{array}$ & $\begin{array}{l}\text { Treated } P . \\
\text { radiata }\end{array}$ \\
\hline$L^{*}$ & 0.000 & 0.000 & 0.000 & 0.002 \\
\hline$a^{*}$ & 0.000 & 0.000 & 0.000 & 0.000 \\
\hline$b^{*}$ & 0.000 & 0.000 & 0.000 & 0.017 \\
\hline Gloss $20^{\circ}$ & 0.000 & 0.000 & 0.463 & 0.109 \\
\hline Gloss $60^{\circ}$ & 0.000 & 0.000 & 0.017 & 0.009 \\
\hline Gloss 85ㅇ & 0.350 & 0.001 & 0.414 & 0.013 \\
\hline Roughness $\left(R_{\mathrm{a}}\right)$ & 0.000 & 0.021 & 0.000 & 0.000 \\
\hline Roughness $\left(R_{\mathrm{z}}\right)$ & 0.001 & 0.080 & 0.002 & 0.370 \\
\hline
\end{tabular}




\section{CONCLUSIONS}

1. With artificial weathering, lightness $\left(L^{*}\right)$ decreased, staying approximately constant afterwards for untreated wood, while smaller changes were observed for heat-treated wood until $750 \mathrm{~h}$.

2. Both untreated and heat-treated wood became more reddish (higher $a^{*}$ ) in the beginning of the weathering process, turning greener (lower $a^{*}$ ) for more severe treatments. At the same time, untreated woods became yellower (higher $b^{*}$ ) in the beginning turning into blueish tones later on (lower $b^{*}$ ). Heat-treated wood generally became yellower.

3. In general, roughness seems to increase with artificial weathering for both untreated and heat-treated wood.

4. Untreated wood glossiness seems to decrease with weathering, while heat-treated wood glossiness remained approximately constant.

5. There was an increase in wettability with artificial weathering, mainly for heat-treated woods.

6. Heat treatment gave some protection to artificial weathering in relation to color and glossiness but not in relation to wettability in the first 750 hours.

\section{ACKNOWLEDGEMENTS}

This work was done in the framework of the project PROJ/CI\&DETS/2016/0010Determination of resistance of thermally treated wood to weather conditions in different countries (HTW). It was funded by National Funds through the FCT - Foundation for Science and Technology, I.P., within the scope of the project $\operatorname{Ref}^{\mathrm{a}}$ UIDB/00681/2020. Furthermore, we would like to thank the CERNAS Research Centre and the Polytechnic Institute of Viseu for their support.

\section{REFERENCES CITED}

Alén, R., Kotilainen, R., and Zaman, A. (2002). "Thermochemical behavior of Norway spruce (Picea abies) at 180-225 C," Wood Science and Technology 36(2), 163-171. DOI: 10.1007/s00226-001-0133-1

Ayadi, N., Lejeune, F., Charrier, F., Charrier, B., and Merlin, A. (2003). "Color stability of heat-treated wood during artificial weathering," Holz als Roh-und Werkstoff 61(3), 221-226.

Ayata, U., Gurleyen, L., and Al, E. (2017a). "Effect of heat treatment on the surface of selected exotic wood species," Drewno 60(199), 105-116. DOI: 10.12841/wood.1644-3985.198.08

Ayata, U., Sahin, S., Esteves, B., and Gurleyen, L. (2017b). "Effect of thermal aging on colour and glossiness of UV system varnish-applied laminated parquet layers," BioResources 13(1), 861-868. DOI: 10.15376/biores.13.1.861-868

Baysal, E., Degirmentepe, S., and Simsek, H. (2014). "Some surface properties of 
thermally modified scots pine after artificial weathering," Maderas. Ciencia y tecnología 16(3), 355-364.

Bekhta, P., Proszyk, S., Lis, B., and Krystofiak, T. (2014). "Gloss of thermally densified alder (Alnus glutinosa Goertn.), beech (Fagus sylvatica L.), birch (Betula verrucosa Ehrh.), and pine (Pinus sylvestris L.) wood veneers," European Journal of Wood and Wood Products 72(6), 799-808. DOI: 10.1007/s00107-014-0843-3

Buchner, J., Irle, M., Belloncle, C., Michaud, F., and Macchioni, N. (2019). "Fungal and bacterial colonies growing on weathered wood surfaces," Wood Material Science \& Engineering 14(1), 33-41. DOI: 10.1080/17480272.2018.1443975

Deka, M., Humar, M., Rep, G., Kričej, B., Šentjurc, M., and Petrič, M. (2008). "Effects of UV light irradiation on colour stability of thermally modified, copper ethanolamine treated and non-modified wood: EPR and DRIFT spectroscopic studies," Wood Science and Technology 42(1), 5-20. DOI: 10.1007/s00226-007-0147-4

Derbyshire, H., and Miller, E. R. (1981). "The photodegradation of wood during solar irradiation," Holz als Roh-und Werkstoff, Springer, 39(8), 341-350.

EN ISO 16474-3 (2013) "Paints and varnishes - methods of exposure to laboratory light sources - part 3: fluorescent UV lamps," European Committee for Standardization, Brussels, Belgium.

Esteves, B. M., and Pereira, H. (2009). "Wood modification by heat treatment: A review," BioResources 4(1), 340-404. DOI: 10.15376/biores.4.1.340-404

Esteves, B., Ayata, U., and Gurleyen, L. (2019). "Effect of heat treatment on the colour and glossiness of black locust, wild pear, linden, alder and willow wood," Drewno 62(203), 39-52.

Esteves, B., Graça, J., and Pereira, H. (2008). "Extractive composition and summative chemical analysis of thermally treated eucalypt wood," Holzforschung 62(3), 344351. DOI: 10.1515/HF.2008.057

Feist, W. C., Rowell, R. M., and Ellis, W. D. (2007). "Moisture sorption and accelerated weathering of acetylated and methacrylated aspen," Wood and Fiber Science 23(1), 128-136.

Gindl, M., Sinn, G., and Stanzl-Tschegg, S. E. (2006). "The effects of ultraviolet light exposure on the wetting properties of wood," Journal of Adhesion Science and Technology 20(8), 817-828. DOI: 10.1163/156856106777638653

Gonzalez de Cademartori, P. H., Missio, A. L., Dufau Mattos, B., and Gatto, D. A. (2015). "Natural weathering performance of three fast-growing Eucalypt woods," Maderas. Ciencia y Tecnología, (ahead), 0-0. DOI: 10.4067/S0718221X2015005000069

Huang, X., Kocaefe, D., Kocaefe, Y., Boluk, Y., and Pichette, A. (2012a). “A spectrocolorimetric and chemical study on color modification of heat-treated wood during artificial weathering," Applied Surface Science 258(14), 5360-5369. DOI: 10.1016/j.apsusc.2012.02.005

Huang, X., Kocaefe, D., Kocaefe, Y., Boluk, Y., and Pichette, A. (2012b). "Changes in wettability of heat-treated wood due to artificial weathering," Wood Science and Technology 46(6), 1215-1237.

Humar, M., Lesar, B., and Kržišnik, D. (2020). "Moisture performance of façade elements made of thermally modified Norway spruce wood," Forests, Multidisciplinary Digital Publishing Institute 11(3), 348.

Kocaefe, D., Huang, X., and Kocaefe, Y. S. (2013). "Comparison of weathering behavior of heat-treated jack pine during different artificial weathering conditions." $4^{\text {th }}$ 
International Conference on Fluid Mechanics and Heat \& Mass Transfer (FLUIDSHEAT'13), June 25-27, 2013, Dubrovnik, Croatia.

Kucuktuvek, M., Baysal, E., Turkoglu, T., Peker, H., Gunduz, A., and Toker, H. (2017). "Surface characteristics of Scots pine wood heated at high temperatures after weathering," Wood Research 62(6), 905-918.

Mayes, D., and Oksanen, O. (2002). "Thermowood handbook," Finnforest, Finland, 515.

Meyer-Veltrup, L., Brischke, C., Alfredsen, G., Humar, M., Flæte, P.-O., Isaksson, T., Brelid, P. L., Westin, M., and Jermer, J. (2017). "The combined effect of wetting ability and durability on outdoor performance of wood: development and verification of a new prediction approach," Wood Science and Technology 51(3), 615-637. DOI: 10.1007/s00226-017-0893-x

Miklecic, J., Jirouš-Rajković, V., Antonović, A., and Španić, N. (2011). "Discolouration of thermally modified wood during simulated indoor sunlight exposure," BioResources 6(1), 434-446. DOI: 10.15376/biores.6.1.434-446

Nuopponen, M., Vuorinen, T., Jämsä, S., and Viitaniemi, P. (2005). “Thermal modifications in softwood studied by FT-IR and UV resonance Raman spectroscopies," Journal of Wood Chemistry and Technology 24(1), 13-26. DOI: 10.1081/WCT-120035941

Oberhofnerová, E., and Pánek, M. (2016). "Surface wetting of selected wood species by water during initial stages of weathering," Wood Research 61(4), 545-552.

Olărescu, C. M., Câmpean, M., and Varodi, A. (2014). "Colour and dimensional modifications of solid wood panels made from heat-treated spruce wood after three months of outdoor exposure," Pro Ligno 10(3), 46-54.

Temiz, A., Terziev, N., Jacobsen, B., and Eikenes, M. (2006). "Weathering, water absorption, and durability of silicon, acetylated, and heat-treated wood," Journal of Applied Polymer Science 102(5), 4506-4513. DOI: 10.1002/app.24878

Turkoglu, T., Toker, H., Baysal, E., Kart, S., Yuksel, M., and Ergun, M. E. (2015). "Some surface properties of heat-treated and natural weathered oriental beech," Wood Research 60(6), 881-890.

Van den Besselaar, E. J. M., Klein Tank, A. M. G., and Buishand, T. A. (2013). "Trends in European precipitation extremes over 1951-2010," International Journal of Climatology 33(12), 2682-2689.

Windeisen, E., Strobel, C., and Wegener, G. (2007). "Chemical changes during the production of thermo-treated beech wood," Wood Science and Technology 41(6), 523-536. DOI: 10.1007/s00226-007-0146-5

Yildiz, S., Tomak, E. D., Yildiz, U. C., and Ustaomer, D. (2013). "Effect of artificial weathering on the properties of heat-treated wood," Polymer Degradation and Stability 98(8), 1419-1427. DOI: 10.1016/j.polymdegradstab.2013.05.004

Article submitted: June 11, 2020; Peer review completed: August 3, 2020; Revised version received and accepted: October 27, 2020; Published: October 30, 2020. DOI: $10.15376 /$ biores.15.4.9642-9655 